\title{
Dynamics of a toxic cyanobacterial bloom (Cylindrospermopsis raciborskii) in a shallow reservoir in the semi-arid region of northeast Brazil
}

\author{
Marc Bouvy ${ }^{1, *}$, Renato Molica ${ }^{2}$, Simone De Oliveira ${ }^{3}$, Mauro Marinho ${ }^{3}$, \\ Beatriz Beker ${ }^{4}$
}

${ }^{1}$ Institut de Recherche pour le Dèveloppement (IRD), 911 Avenue Agropolis, 34032, Montpellier cedex 1, France

${ }^{2}$ Instituto Tecnológico do Estado de Pernambuco (ITEP), Recife/PE, Brazil

${ }^{3}$ Universidade Federal Rural de Pernambuco, Recife/PE 52175-030, Brazil

${ }^{4}$ Centre Océanologique de Marseille (COM), rue de la Batterie des Lions, 13007 Marseille, France

\begin{abstract}
The species composition and the seasonal succession of phytoplankton were analyzed in a eutrophic drinking water reservoir located in the semi-arid region of northeast Brazil. Investigations were based on bimonthly or monthly sampling over 2 yr (1997 to 1998) conducted at 1 representative station with 2 sampled depths $(0.5$ and $5 \mathrm{~m}$ near the bottom). Limnological parameters (temperature, $\mathrm{pH}$, dissolved oxygen, conductivity, light, dissolved inorganic nutrients) were simultaneously measured to determine the possible factors affecting the phytoplankton composition. We determined 30 taxa during the survey which were numerically dominated by the class Chlorophyceae. However, both in terms of abundance and biomass, Cyanobacteria dominated the phytoplankton community with Cylindrospermopsis raciborskii (Wolsz.) Seenayya et Subba Raju. This species can represent biomass close to $96-100 \%$ of total phytoplankton biomass, with values reaching $70 \mathrm{mg} \mathrm{l}^{-1}$ (fresh weight) between April and November 1998. Over the survey, the filaments of C. raciborskii were coiled (average of $97 \%$ ) with a mean proportion of $12.3 \%$ of terminal heterocytes. The species toxicity was determined from bioassay analysis and the presence of neurotoxins was revealed during the bloom. By March 1998, chlorophyll concentration reached $135 \mu \mathrm{g}^{-1}$ at the surface level, inducing a sharp decrease of the euphotic zone depth. Favorable environmental conditions were observed for the bloom with high temperatures, high $\mathrm{pH}$, low N/P ratio, and absence of efficient predators. The nutrient context seemed to play a role in the cyanobacterial bloom despite the absence of external nutrient supply. However, annual rain deficit and lack of water renewal in 1998 linked to the 1997 El Niño consequences seem to be the major factors responsible for both hypereutrophic conditions and cyanobacterial blooms in the reservoir studied. Thus, global climate change can influence phytoplankton population dynamics in continental waters, as demonstrated frequently in oceanic ecosystems.
\end{abstract}

KEY WORDS: Phytoplankton - Cylindrospermopsis raciborskii - Eutrophication - El Nin̄o event Shallow reservoir

\section{INTRODUCTION}

Functional morphology, growth requirements and adaptive strategies of freshwater phytoplankton have been well described over the last few decades from detailed studies at an algal species and/or community

\footnotetext{
•E-mail: bouvy@mpl.ird.fr
}

level (e.g. Reynolds 1988, 1998). Dominance of a particular species within a phytoplankton community depends upon a complex of factors including physical (e.g. retention time), chemical (e.g. nutrient loading) and biological (e.g. grazing) symptoms. Cyanobacteria are commonly encountered in many eutrophic reservoirs, and are known to contribute by their blooms to the deterioration in the aquatic environment. Identify- 
ing the specific environmental factors which promote the cyanobacterial blooms is a crucial question for many researchers, and it is obvious that no single factor may serve as a reliable predictor. Establishment of causality between physico-chemical, biological or climatological factors and cyanobacterial blooms is an important issue for the effective management of reservoirs. Cyanobacterial blooms are often preceded by nutrient enrichment which coincides with environmental changes such as stratification and/or temperature elevation and/or absence of zooplankton grazing (Paerl 1988, Reynolds 1998). Few studies have focused on how changes in water quality parameters are related to the increase in cyanobacterial abundances (Fabbro \& Duivenvoorden 1996, James \& Havens 1996, Soranno 1997, de Souza et al. 1998). On the other hand, the influence of local climatological factors (e.g. wind, light conditions) can also modify the phytoplankton siruciure, as cyanobacteria communities are strongly driven by physical conditions such as local weather (e.g. Tóth \& Padisák 1986, Paerl 1988, Townsend et al. 1996, Soranno 1997). Other climatological factors which play a role in the global climate have been recently studied in marine ecosystems, such as the El Niño-Southern Oscillation (ENSO) cycles in the modification of phytoplankton communities (e.g. Barber et al. 1996, Blanchot \& Rodier 1996). However, few works about these El Nin̄o episodes have been carried out on continental waters, and studies on the effects of global warming on phytoplankton population dynamics are especially very scarce (Harris \& Baxter 1996, Padisák 1998). Harris \& Baxter (1996) reported in a subtropical reservoir that many cyanobacterial blooms appear to be linked to a decrease in total water capacity due to the severe droughts linked to the successive El Nin̄o events. In addition, Padisák (1998) concluded that the positive deviation of temperature (close to $2^{\circ} \mathrm{C}$ ) can explain the interannual variability of cyanobacterial blooms in Lake Balaton, Hungary.

The northeastern region of Brazil is home to a large semi-arid expanse referred as the Drought Polygon. For the past $100 \mathrm{yr}$, combating droughts in this region has been accomplished primarily by providing surface water storage, and the reliance on surface reservoirs has been referred to as the 'Açudes' (Brazilian name for reservoir, generally man-made) policy. The main surface water sources are reservoirs with more than 70000 systems with $1000 \mathrm{~m}^{2}$ and even more with lower surface (Molle 1991). Although many are used as sources for treated water consumption, most are designed for multiple purposes such as unrestricted irrigation, bathing, fishing and ranching. Freshwater cyanobacteria also pose a potential risk to human health, livestock and other animals if these cells liberate toxins in water (Carmichael 1994, Jones \& Poplaw- ski 1998). Cyanobacteria produce a wide range of toxins including the cyclic peptide hepatotoxins and alkaloid neurotoxins such as paralytic shellfish poisons (PSPs) (Carmichael 1994, Humpage et al. 1993). A severe outbreak of hepato-enteritis occurred at a haemodialysis center in Pernambuco state, Brazil, in February 1996, with the death of 60 patients due to the use of a water reservoir colonized by cyanobacteria (Azevedo 1996, Carmichael 1996, Jochimsen et al. 1998). Among toxic cyanobacteria, the genus Cylindrospermopsis is well represented, as some species ( $C$. raciborskii) dominate major components of phytoplankton communities and may form water blooms in tropical freshwater ecosystems (e.g. Branco \& Senna 1994 in Brazil, Fabbro \& Duivenvoorden 1996 in Australia). Recently, Padisák (1997) concluded in a review that $C$. raciborskii has become one of the most notorious cyanobacteria over the world because of its potential toxicity and tendency to form dense blooms.

In 1997, as a direct consequence of the El Niño event (Liu et al. 1998), irregularities in precipitation and reduction of the rainy seasons were observed in the Brazilian semi-arid region. By March 1998, water levels in reservoirs drastically decreased, favoring eutrophication and development of Cylindrospermopsis raciborskii (Bouvy et al. 1998b, Molica et al. 1998). In the framework of the 'Açudes Project', initiated in 1994 with the Brazilian partners of the Recife University of Pernambuco, a limnological study has focused on studies of the trophic structure of many reservoirs between 1996 and 1998. This paper presents the dynamics of a cyanobacterial bloom in 1 reservoir through studies of seasonal variations over 2 yr (1997 to 1998) and its consequences related to the environmental and climatological factors studied.

\section{MATERIALS AND METHODS}

Study area. Ingazeira reservoir is situated between $8^{\circ} 34^{\prime} \mathrm{S}$ and $36^{\circ} 52^{\prime} \mathrm{W}_{\text {; }}$ (see Fig. 1), in the south of Pernambuco state, $250 \mathrm{~km}$ from the Atlantic Ocean. It was built in 1986 to retain water for irrigation and drinking purposes. Its direct catchment area covers a surface of $326 \mathrm{~km}^{2}$ and the lake surface is 130 ha at maximum capacity (theoretical volume of $4.6 \times 10^{6} \mathrm{~m}^{3}$ ). At this optimal capacity, the mean depth is of $5 \mathrm{~m}$ with a maximum depth of $13 \mathrm{~m}$ in front of the dam. The first investigation, carried out in September 1995 (Bouvy et al. 1998a), concluded that the characteristics of this reservoir are close to the mesotrophic state (e.g. chlorophyll level of $19 \mu \mathrm{g} \mathrm{l}^{-1}$ ).

The hydrological balance in this Brazilian region is characterized by an annual precipitation range between 400 and $800 \mathrm{~mm}$ (Cadier 1993). The historical annual 
average precipitation is $708 \mathrm{~mm}$ (1920 to 1985 period) with a well-defined rainy season between January and July (Fig. 2). In 1997, this value was lower at $507 \mathrm{~mm}$ with many irregularities in precipitation. In 1998, the precipitation decreased dramatically, with an average annual rainfall of $113 \mathrm{~mm}$, as a direct consequence of the 1997 El Niño event. The water level in Ingazeira reservoir has suffered a $5.2 \mathrm{~m}$ decrease between January 1997 and December 1998.

Sampling and analysis procedures. Samples were collected at a fixed station in front of the dam, at bimonthly intervals from January 1997 to March 1998. Between March and December 1998, samples were taken monthly in order to follow the cyanobacterial bloom. Water temperature, $\mathrm{pH}$ and dissolved oxygen were measured through the water column at intervals of $0.5 \mathrm{~m}$ from the surface to the bottom, using a hydrostatic pump and specific electrodes (YSI probe and $\mathrm{pH}$ probe). From PAR measurements using a Li-Cor 193 spherical quantum sensor $(4 \pi)$, the vertical attenuation coefficient $(K)$ was calculated from a linear regression analysis of the natural logarithm of irradiance with respect to depth. From this coefficient, the depth of the $1 \%$ light level, analogous to the euphotic zone, was obtained for each sampling.

Water samples for nutrients, phytoplankton and chlorophyll concentrations were taken with a 2 l vertucai iviskin borrie al $\bar{Z}$ salnpürngs ieveis, $-\hat{u} . \bar{J}$ anui $-5 \mathrm{~m}$ near the bottom. The samples for dissolved nutrients $\left(\mathrm{NH}_{4}-\mathrm{N}, \mathrm{NO}_{3}-\mathrm{N}, \mathrm{NO}_{2}-\mathrm{N}, \mathrm{PO}_{4}-\mathrm{P}\right)$ determinations were filtered onto Whatman GF/F fiberglass filters, stored at $-20^{\circ} \mathrm{C}$ and analyzed according to Strickland and Parsons (1972). Water samples for chlorophyll analysis were filtered onto Whatman GF/F filters and stored in liquid nitrogen. Chlorophyll a concentrations were determined fluorometrically after methanol extraction (Yentsch \& Menzel 1963). Water samples for phytoplankton analysis were immediately preserved in Lugol's iodine solution, stored in dark and cold conditions $\left(4\right.$ to $6^{\circ} \mathrm{C}$ ). After sedimentation (for $24 \mathrm{~h}$, chambers of $2 \mathrm{ml}$ for the dominant species, and $10 \mathrm{ml}$ for other algae), phytoplankton species were enumerated by inverted microscopy (Utermohl's method) in random fields (Uhelinger 1964) given precision of $10 \%$. The species Cylindrospermopsis raciborskii has been identified and confirmed by Dr Jaroslava Komárková, from the Institute of Hydrobiology, Czech Republic. Wet biomass was calculated from recorded abundance and specific biovolumes assuming a specific gravity of 1 . Cell volumes based on measured dimensions were estimated for each species from geometric solids (Rott 1981). Phytoplankton diversity was expressed by the Shannon-Weaver index (Shannon \& Weaver 1963) based on biomass of each species according to the formula:

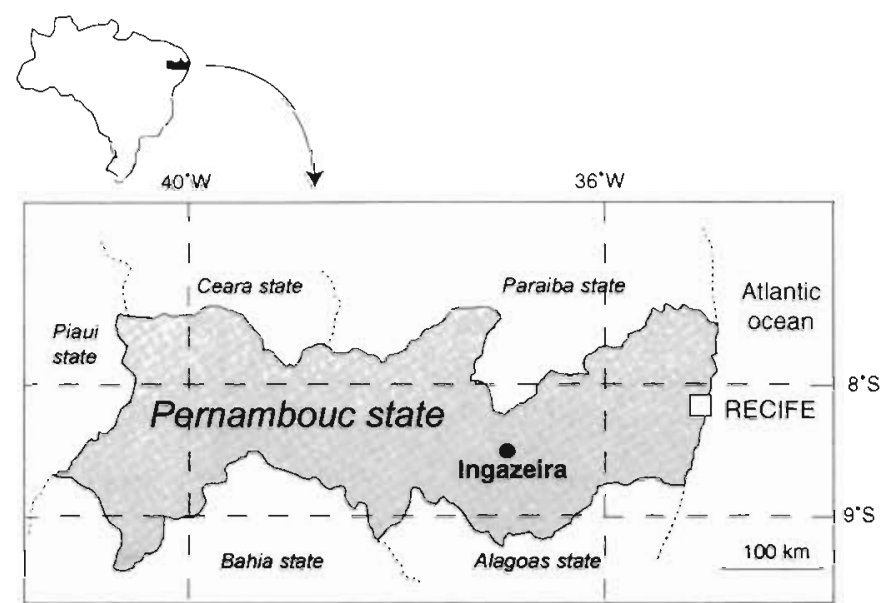

Fig. 1. Map of Pernambuco state (Brazil) and location of the Ingazeira reservoir

$$
H\left(\text { bits cell }{ }^{-1}\right)=-\sum n_{j} / N \times \log _{2}\left(n_{i} / N\right)
$$

where $n_{i}$ is the measure of the ith species (as specific wet biomass) and $N$ is total biomass.

Data were analyzed using the statistical software package SigmaStat (Jandel Corp.), and Spearman rank correlation coefficients were used to measure the degree of association between the abiotic parameters and the algal variables.

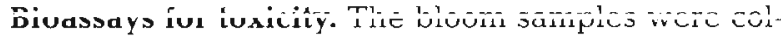
lected 3 times (April, September and October 1998) in plastic bottles (4 1). At the laboratory the samples were rapidly concentrated by centrifugation and then stored at $-18^{\circ} \mathrm{C}$. Freeze-thawed samples were used for bioassay analysis by intra-peritoneal injection into Swiss Albino mice ( 25 to $32 \mathrm{~g}$ body weight) and into Tilapia fishes Oerochromis niloticus (10 to $20 \mathrm{~g}$ body weight). This fish dominates the fish community of Ingazeira reservoir.

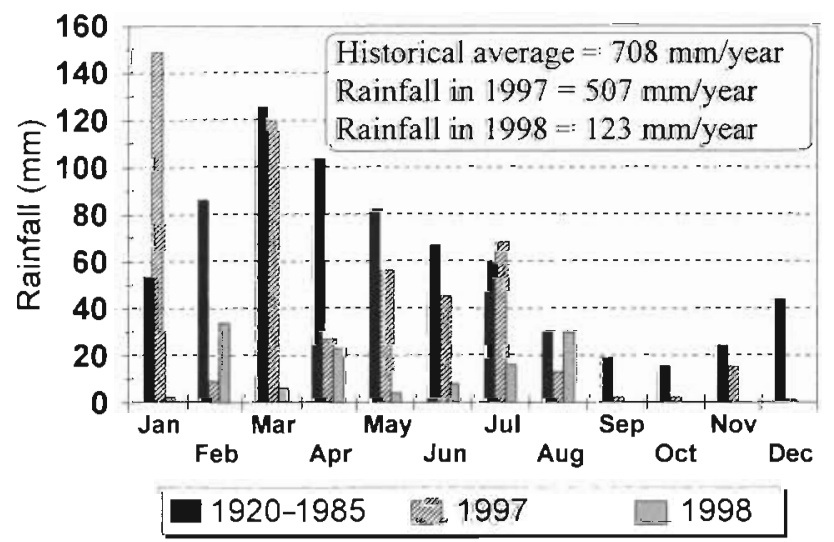

Fig. 2. Monthly average precipitation for the 1920 to 1985 period and for the 2 yr studied (1997 and 1998) 


\section{RESULTS}

\section{Physico-chemical parameters}

Due to the lack of precipitation, the water level decreased continuously from August 1997 (full total capacity) until the end of the survey in December 1998 ( $20 \%$ of the total volume; Fig. 3 ). The reservoir completely dried in June 1999 due to an evaporation rate of $3 \mathrm{~m} \mathrm{yr}^{-1}$ in this region (Cadier 1993) and the water being used for drinking. Due to the very low volume of catchment inflow in 1998 (Fig. 2), a theoretical retention time is approximately 2 yr for our survey. Variations of conductivity values showed an inverse pattern of total volume fluctuations, with an increase of salt concentrations throughout the survey starting from April 1997 (Table 1). Values were generally lower at $5 \mathrm{~m}$. The depth of the euphotic zone showed a clear pattern with high values in 1997 (January and August; close to $2.5 \mathrm{~m}$ ) and the lowest observed between April and August 1998. The minimum value $(53 \mathrm{~cm})$ was recorded in June 1998 and corresponded to an attenuation coefficient of $8.7 \mathrm{~m}^{-1}$ (Table 1). Photon flux density at $0.5 \mathrm{~m}$ varied during the survey, with the lowest values $\left(<63 \mu \mathrm{E} \mathrm{m}^{-2} \mathrm{~s}^{-1}\right)$ noted between April and September 1998 (Table 1).

Fig. 4 represents the depth-time contour lines for temperature, $\mathrm{pH}$ and dissolved oxygen in Ingazeira reservoir. Water temperatures were always high during the survey with minima at $0.5 \mathrm{~m}$ (subsurface) registered in June and August $\left(24\right.$ to $25.3^{\circ} \mathrm{C}$ ). Temperature profiles did not show vertical stratification: according to the season, the general cooling and warming of the

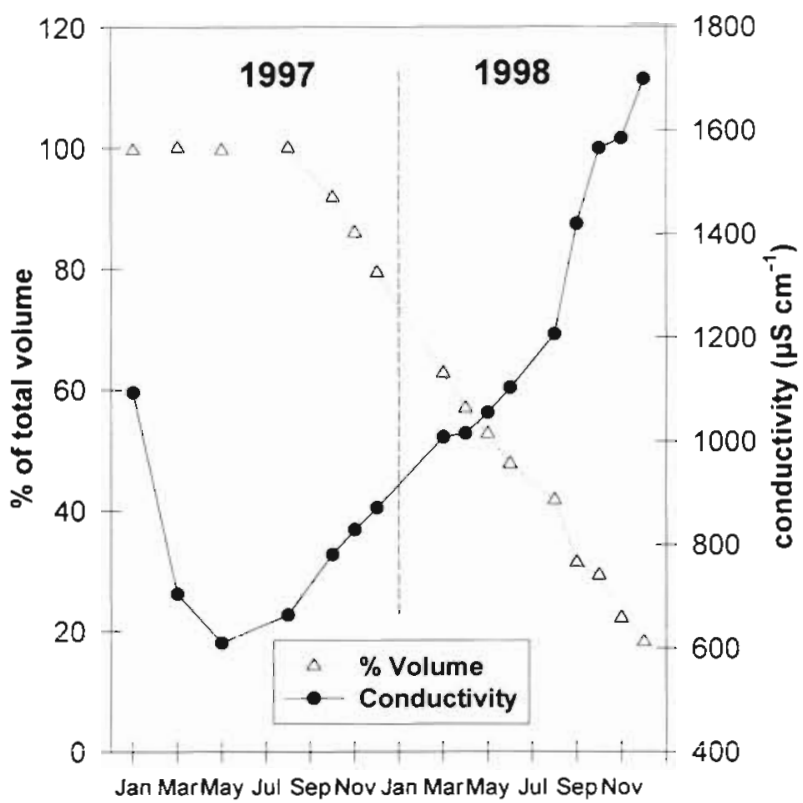

Fig. 3. Fluctuations of conductivity and total reservoir volume from January 1997 to December 1998

water column affected all the water column down to the bottom. From October to December 1998, water temperatures in the upper column were slightly higher, inducing a thermal stratification of the water column between 0.5 and $1 \mathrm{~m}$ (Fig. 4A). Surface pH values were always above 8.12 and reached up to 9.39 in March 1998 (Fig. 4B). The high pH values corresponded to extremely high oxygen concentrations in March and April 1998. Surface $\mathrm{pH}$ values were higher

Table 1. Euphotic depth $\left(Z_{\text {euph }}\right)$, vertical attenuation coefficient of irradiance $\left(K_{\mathrm{d}}\right)$, light intensity at $0.5 \mathrm{~m}$, conductivity values, chlorophyll levels, algal density and biomass, Shannon-Wiever (S-W) index for each depth during the survey between January 1997 and December 1998 in Ingazeira reservoir. S: $0.50 \mathrm{~m}$ depth; B: $5 \mathrm{~m}$ depth

\begin{tabular}{|c|c|c|c|c|c|c|c|c|c|c|c|c|c|c|c|c|c|}
\hline & Units & Level & Jan & Mar & May & Aug & Oct & Dec & Mar & Apr & May & Jun & Aug & Sep & Oct & Nov & Dec \\
\hline$Z_{\text {euph }}$ & $M$ & & 2.67 & 2.30 & 1.62 & 2.57 & 0.95 & 1.80 & 0.93 & 0.71 & 0.64 & 0.53 & 0.61 & 0.82 & 0.99 & 0.92 & 0.89 \\
\hline$K_{\mathrm{d}}$ & $\mathrm{m}^{-1}$ & & 1.72 & 2.00 & 2.84 & 1.79 & 4.85 & 2.55 & 4.95 & 6.48 & 7.19 & 8.68 & 7.54 & 5.61 & 4.65 & 5.00 & 5.17 \\
\hline Light intensity & $\mu \mathrm{E} \mathrm{m}^{-2} \mathrm{~s}^{-1}$ & S & 233 & 230 & 500 & 650 & 141 & 180 & 140 & 15 & 63 & 14 & 23 & 33 & 169 & 180 & 169 \\
\hline Conductivity & $\mu \mathrm{S} \mathrm{cm}^{-1}$ & $\begin{array}{l}\mathrm{S} \\
\mathrm{B}\end{array}$ & $\begin{array}{l}1095 \\
1086\end{array}$ & $\begin{array}{l}706 \\
727\end{array}$ & $\begin{array}{l}611 \\
597\end{array}$ & $\begin{array}{l}665 \\
668\end{array}$ & $\begin{array}{l}782 \\
789\end{array}$ & $\begin{array}{l}872 \\
893\end{array}$ & $\begin{array}{l}1009 \\
1019\end{array}$ & $\begin{array}{l}1016 \\
1018\end{array}$ & $\begin{array}{l}1056 \\
1053\end{array}$ & $\begin{array}{l}1104 \\
1085\end{array}$ & $\begin{array}{l}1208 \\
1173\end{array}$ & $\begin{array}{l}1420 \\
1270\end{array}$ & $\begin{array}{l}1566 \\
1318\end{array}$ & $\begin{array}{l}1585 \\
1321\end{array}$ & $\begin{array}{l}1700 \\
1736\end{array}$ \\
\hline Chlorophyll & $\mu \mathrm{g} \mathrm{I}^{-1}$ & $\begin{array}{l}\text { S } \\
B\end{array}$ & $\begin{array}{l}30.2 \\
23.3\end{array}$ & & & & $\begin{array}{l}55.7 \\
55.2\end{array}$ & $\begin{array}{l}35.1 \\
37.8\end{array}$ & $\begin{array}{l}65.6 \\
65.3\end{array}$ & $\begin{array}{l}70.8 \\
58.3\end{array}$ & & & & $\begin{array}{l}97.4 \\
85.1\end{array}$ & $\begin{array}{l}42.1 \\
36.4\end{array}$ & $\begin{array}{l}38.1 \\
34.4\end{array}$ & $\begin{array}{l}51.4 \\
46.8\end{array}$ \\
\hline Algal density & $10^{6} \mathrm{cell}^{-1}$ & $\begin{array}{l}\mathrm{S} \\
\mathrm{B}\end{array}$ & $\begin{array}{l}19.1 \\
19.6\end{array}$ & $\begin{array}{c}36.8 \\
8.1\end{array}$ & $\begin{array}{c}70.8 \\
4.4\end{array}$ & $\begin{array}{l}35.1 \\
22.7\end{array}$ & $\begin{array}{l}86.8 \\
48.5\end{array}$ & $\begin{array}{l}74.5 \\
19.5\end{array}$ & $\begin{array}{l}157.0 \\
198.1\end{array}$ & $\begin{array}{l}177.0 \\
374.5\end{array}$ & & $\begin{array}{l}120.1 \\
150.2\end{array}$ & $\begin{array}{c}84.3 \\
130.3\end{array}$ & $\begin{array}{l}89.4 \\
99.3\end{array}$ & $\begin{array}{l}92.3 \\
91.3\end{array}$ & $\begin{array}{l}68.1 \\
92.1\end{array}$ & $\begin{array}{c}56.7 \\
154.2\end{array}$ \\
\hline Algal biomass & $\underset{(\mathrm{fw})}{\mathrm{mg} \mathrm{l^{-1 }}}$ & $\begin{array}{l}\text { S } \\
\text { B }\end{array}$ & $\begin{array}{l}9.3 \\
7.7\end{array}$ & $\begin{array}{l}30.1 \\
10.3\end{array}$ & $\begin{array}{c}66.8 \\
4.7\end{array}$ & $\begin{array}{l}6.6 \\
5.7\end{array}$ & $\begin{array}{l}45.5 \\
27.1\end{array}$ & $\begin{array}{l}43.1 \\
10.2\end{array}$ & $\begin{array}{l}92.8 \\
11.8\end{array}$ & $\begin{array}{c}114.9 \\
28.1\end{array}$ & $\begin{array}{c}119.4 \\
43.1\end{array}$ & $\begin{array}{c}106.7 \\
33.4\end{array}$ & $\begin{array}{l}68.8 \\
23.9\end{array}$ & $\begin{array}{l}67.7 \\
19.6\end{array}$ & $\begin{array}{l}20.9 \\
11.8\end{array}$ & $\begin{array}{l}29.3 \\
19.7\end{array}$ & $\begin{array}{l}32.9 \\
23.1\end{array}$ \\
\hline S-W index & bits cell ${ }^{-1}$ & $\begin{array}{l}\mathrm{S} \\
\mathrm{B}\end{array}$ & $\begin{array}{l}0.182 \\
0.364\end{array}$ & $\begin{array}{l}0.903 \\
0.671\end{array}$ & $\begin{array}{l}0.242 \\
0.195\end{array}$ & $\begin{array}{l}1.370 \\
1.611\end{array}$ & $\begin{array}{l}0.499 \\
0.423\end{array}$ & $\begin{array}{l}0.069 \\
0.057\end{array}$ & $\begin{array}{l}0.052 \\
0.058\end{array}$ & & & $\begin{array}{l}0.014 \\
0.151\end{array}$ & $\begin{array}{l}0.012 \\
0.001\end{array}$ & - & $\begin{array}{l}0.075 \\
0.007\end{array}$ & $\begin{array}{l}0.659 \\
0.038\end{array}$ & $\begin{array}{l}0.824 \\
0.338\end{array}$ \\
\hline
\end{tabular}



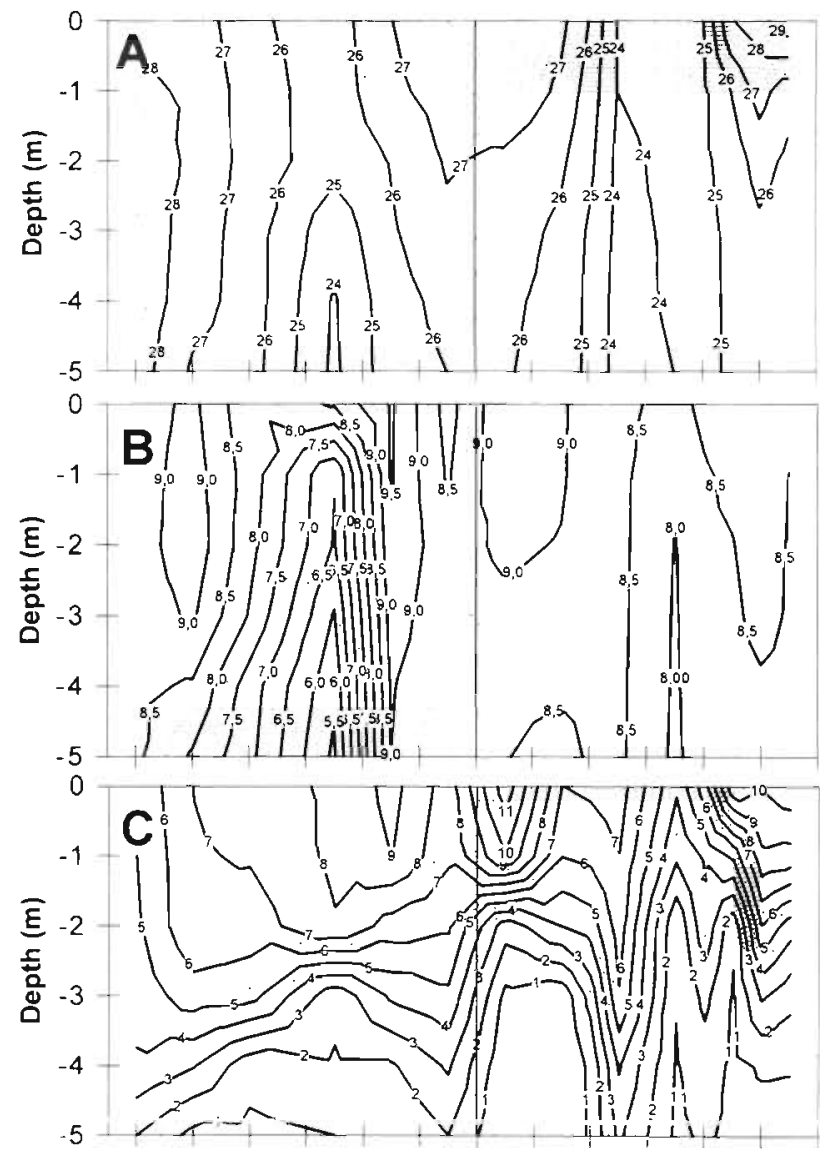

Jan Mar May Jul Sep Nov Jan Mar May Jul Sep Nov

Fig. 4. Depth-time contour lines for $(\mathrm{A})$ temperature $\left({ }^{\circ} \mathrm{C}\right),(\mathrm{B})$ $\mathrm{pH}\left(\mathrm{pH}\right.$ units) and $(\mathrm{C})$ dissolved oxygen $\left(\mathrm{mg} \mathrm{l}^{-1}\right)$ during the survey

than those observed at $5 \mathrm{~m}$, but the vertical distribution of $\mathrm{pH}$ did not show seasonal stratification. In 1998, the vertical profiles showed a great homogeneity of the water column compared with those observed in 1997 (Fig. 4B). On the contrary, dissolved oxygen values presented a well-marked stratification. Throughout the survey, water was supersaturated at $0.5 \mathrm{~m}$ with oxygen concentrations exceeding $7 \mathrm{mg}^{-1}$, while the values decreased dramatically with depth. The oxygenated zone comprised the first $3 \mathrm{~m}$ until December 1997, and was limited to the first meter in December 1998. Anoxic conditions generally occurred in the hypolimnion and were probably due to the lack of strong winds (Fig. 4C).

Soluble reactive phosphorus (SRP) concentrations decreased from high values observed in February 1997 (380 and $544 \mu \mathrm{g} \mathrm{l}^{-1}$, respectively at 0.5 and $5 \mathrm{~m}$ ) to low values in September 1998 ( $6 \mu \mathrm{g} \mathrm{l}^{-1}$ for the 2 levels studied). During the survey, no significant difference of concentrations was observed between the 2 levels studied, with

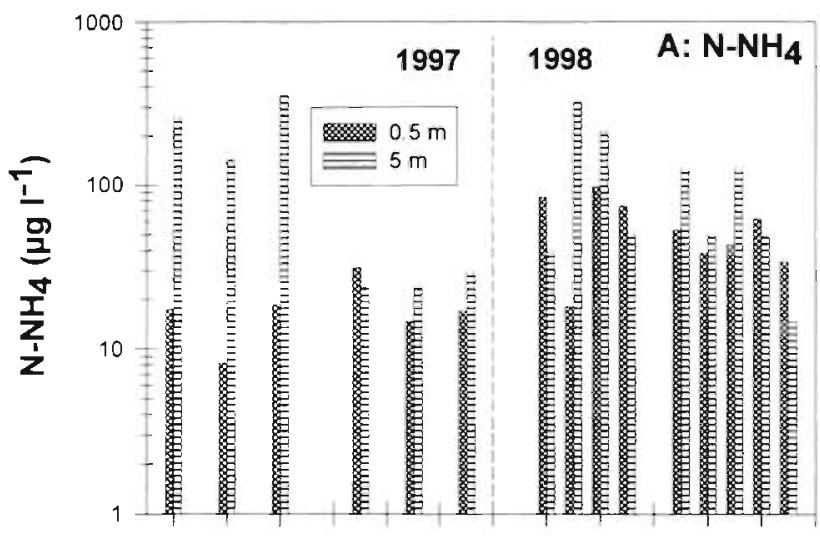

Jan Mar May Jul Sep Nov Jan Mar May Jul Sep Nov

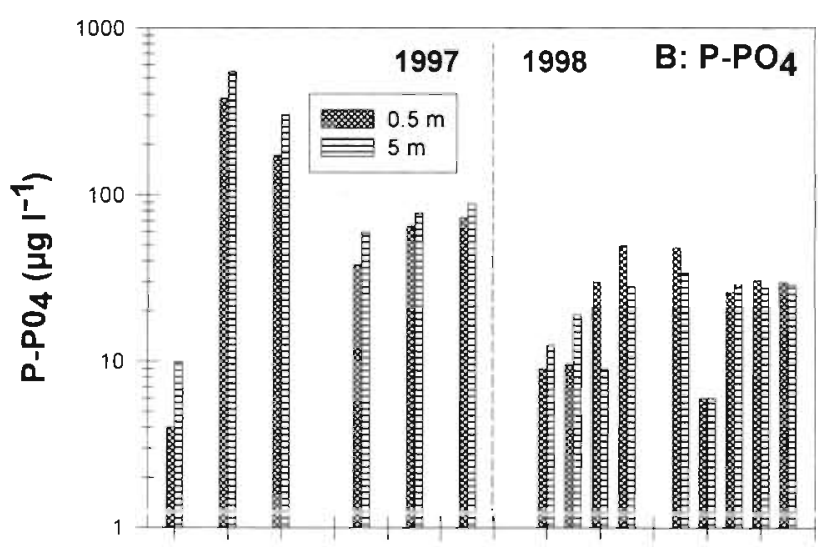

Jan Mar May Jul Sep Nov Jan Mar May Jul Sep Nov

Fig. 5. Temporal variations in ammonium and soluble reactive phosphate concentrations (logarithmic scale) at 2 sampled levels $(0.5$ and $5 \mathrm{~m})$ in 1997 and 1998

a mean of 65 and $85 \mathrm{mg} \mathrm{l}^{-1}$, respectively at 0.5 and $5 \mathrm{~m}$. Ammonium concentrations ranged at $0.5 \mathrm{~m}$ between 8 and $98 \mu \mathrm{g} \mathrm{l}^{-1}$ (mean of $41 \mu \mathrm{g} \mathrm{l}^{-1}$ ) with the highest values from May 1998 (Fig. 5). Large variations of this compound were recorded between the surface and the bottom, with higher values recorded at $5 \mathrm{~m}$ (close to $350 \mu \mathrm{g}$ $\mathrm{I}^{-1}$ in May 1997 and April 1998). Due to technical problems, the nitrate analyses only began in 1998. Oxidized nitrogen (nitrite and nitrate) ranged from 1.3 to $80.2 \mu \mathrm{g}$ $\mathrm{l}^{-1}$ at $0.5 \mathrm{~m}$ and 7.7 to $91.7 \mu \mathrm{g} \mathrm{l}^{-1}$ at $5 \mathrm{~m}$ with low values in November and December 1998. The highest values were recorded in May. The dissolved inorganic $\mathrm{N} / \mathrm{P}$ ratio (by weight) averaged 3.5 at $0.5 \mathrm{~m}$ and 9.2 at $5 \mathrm{~m}$ with values close to 2 in December 1998. Chlorophyll a concentrations at $0.5 \mathrm{~m}$ ranged between $25.9 \mu \mathrm{g} \mathrm{l}^{-1}$ in March 1997 and $135.4 \mathrm{\mu g} \mathrm{l}^{-1}$ in June 1998. The pattern was very similar at $5 \mathrm{~m}$ with the highest values close to $140 \mu \mathrm{g} \mathrm{l}^{-1}$ in August 1998. For the 2 depths studied the period with the highest chlorophyll concentrations was observed between May and September 1998 (Table 1, Fig. 6). 


\section{Species composition and phytoplankton biomass}

The relative abundance and biomass of phytoplankton community showed an obvious pattern during the survey. In 1997, abundances at $0.5 \mathrm{~m}$ were all above $5 \times 10^{7}$ filaments $\mathrm{l}^{-1}$ and biomasses above $70 \mathrm{mg} \mathrm{l}^{-1}$ (fresh weight). In 1998, maxima were recorded between March and October 1998, with $2.2 \times 10^{8}$ filaments $\mathrm{l}^{-1}$ at $0.5 \mathrm{~m}$ in May and $3.7 \times 10^{8}$ filaments $\mathrm{l}^{-1}$ at $5 \mathrm{~m}$ in April. No significant difference was found in total abundance for the 2 levels studied. In contrast, phytoplankton biomass was strongly reduced at $5 \mathrm{~m}$.

Table 2. Phytoplankton species for each depth studied from Ingazeira reservoir between January 1997 and December 1998. S: $0.5 \mathrm{~m}$ depth; B: $5 \mathrm{~m}$ depth

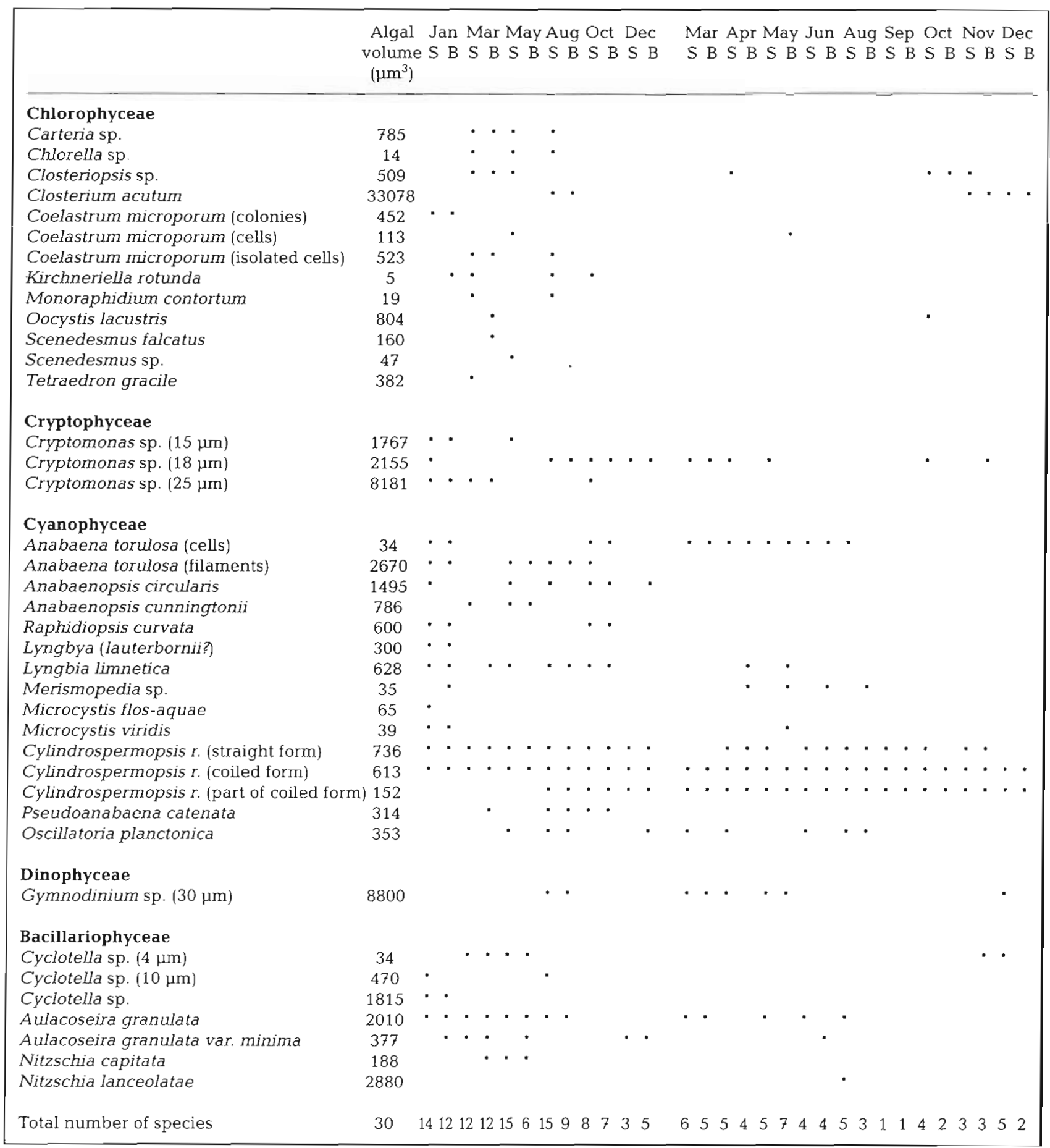


Table 2 lists the taxa which contributed to the total phytoplankton biomass during the study period. There were 30 species identified, with the largest number of species belonging to Chlorophyceae, followed by Cyanobacteria. Organisms belonging to Cryptophyceae, Dinophyceae and Bacillariophyceae are not very important members of the phytoplankton community. In terms of abundance and biomass, Cyanobacteria dominated the phytoplankton community throughout the survey (mean of 90.3 and $95.5 \%$ for the 2 levels studied) with the permanent presence of Cylindrospermopsis raciborskii. This population increased dramatically between April and November 1998 and reached, in term of biomass, proportions of 96 to $100 \%$ of the phytoplankton community. This species was represented by both straight and coiled forms at $0.5 \mathrm{~m}$ (close to $700 \mu \mathrm{m}^{3}$ ), but the coiled form dominated with a mean of $98 \%$ during the survey. In the deeper zone, small parts of coiled form (close to $100 \mu^{3}$ ) were generally observed, explaining the lower algal biomass observed at this level. During the bloom, scums were frequently observed early in the morning at the water surface with a predominance of the coiled form. The second group was represented by Chlorophyceae, only present in March and June 1997 (before the bloom) and in November and December at $5 \mathrm{~m}$ (after the bloom). The other groups were very low in number

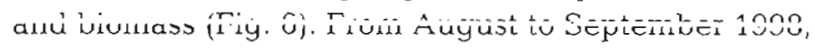
all values decreased down to pre-bloom concentrations.

The Shannon diversity function showed low values during the study with a mean of 0.33 and 0.29 bits

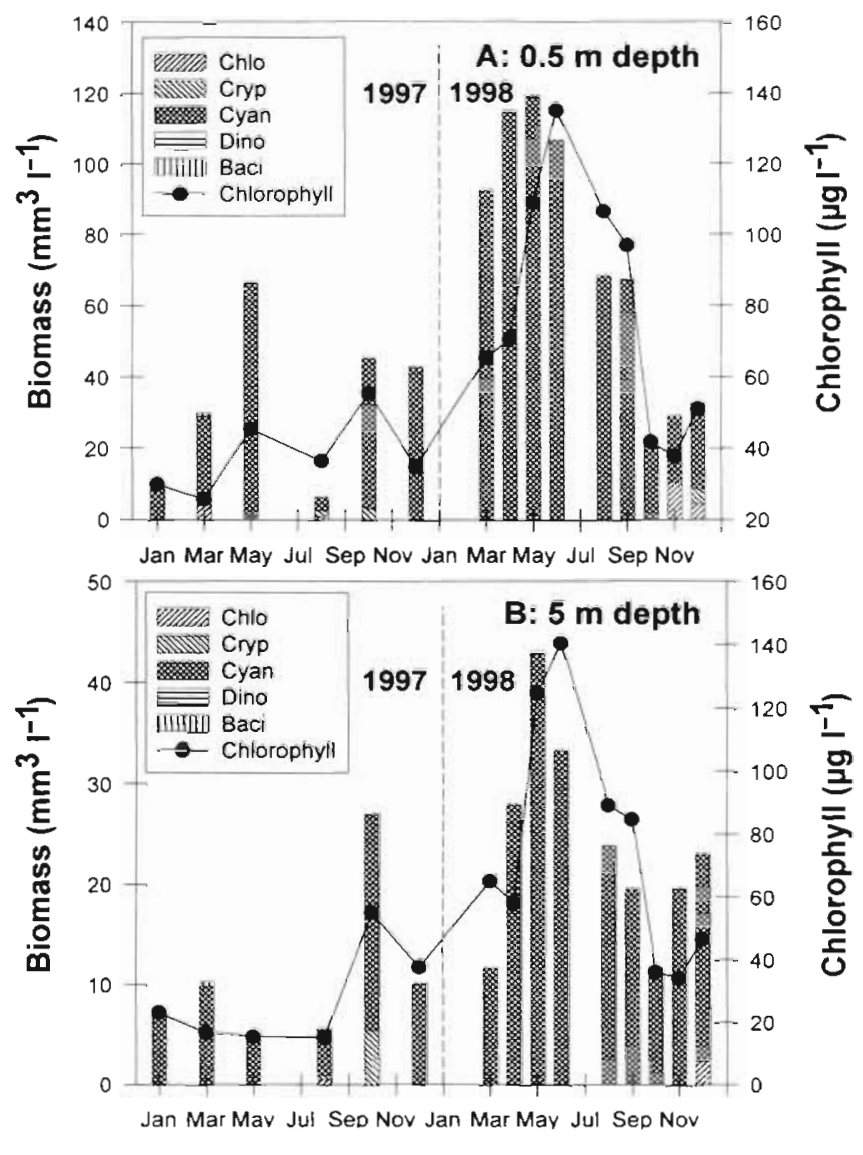

Fig. 6. Time course of phytoplankton biomass of different taxonomic groups, and of chlorophyll concentrations in 1997 to 1998. Chlo: Chlorophyceae; Cryp: Cryptophyceae; Cyan: Cyanophyceae; Dino: Dinophyceae; Baci: Bacillariophyceae

Table 3. Spearman correlation coefficients $(n=15)$ for the algal variables (the 5 phytoplanktonic groups, the $C y l i n d r o s p e r m o p s i s$ species and the Shannon index) and the abiotic variables studied at $0.5 \mathrm{~m}$ depth for the Ingazeira reservoir, January 1997 to December 1998. Significant values $(p<0.05$ ) are given in bold. Pigm: chlorophyll pigments; Depth: depth of euphotic zone; Cond: conductivity; $\mathrm{NH}_{4}$ : ammonium; $\mathrm{PO}_{4}$ : ortophosphate; Temp: temperature; Oxyg: dissolved oxygen

\begin{tabular}{|c|c|c|c|c|c|c|c|c|c|c|c|c|c|c|c|c|}
\hline & Chlor & Crypt & Cyano & Dino & Bacil & Cylind & Index & Pigm & Depth & Seston & Cond & $\mathrm{NH}_{4}$ & $\mathrm{PO}_{4}$ & Temp & Oxyg & $\mathrm{pH}$ \\
\hline Chlor & $\cdots$ & 0.11 & -0.44 & 0.18 & 0.21 & -0.44 & 0.55 & -0.39 & 0.05 & 0.03 & 0.35 & 0.01 & 0.27 & 0.48 & 0.33 & 0.16 \\
\hline Crypt & & $\cdots \cdots$ & -0.33 & 0.93 & -0.24 & -0.33 & 0.51 & -0.21 & -0.02 & 0.08 & 0.11 & -0.26 & -0.12 & 0.35 & 0.42 & 0.27 \\
\hline Cyano & & & $\cdots$ & -0.23 & -0.07 & 0.99 & -0.66 & 0.78 & -0.66 & 0.48 & -0.11 & 0.52 & -0.19 & -0.43 & -0.22 & 0.03 \\
\hline Dino & & & & $\cdots$ & -0.19 & -0.23 & 0.34 & -0.11 & -0.19 & 0.25 & 0.31 & -0.17 & -0.09 & 0.44 & 0.42 & 0.28 \\
\hline Bacil & & & & & $\cdots \cdots$ & -0.11 & 0.29 & -0.21 & 0.44 & -0.41 & -0.43 & -0.15 & 0.84 & 0.04 & -0.29 & 0.06 \\
\hline Cylind & & & & & & $\cdots \cdots$ & -0.68 & 0.79 & -0.68 & 0.51 & -0.08 & 0.54 & -0.23 & -0.43 & -0.21 & 0.01 \\
\hline Index & & & & & & & $\cdots$ & -0.55 & 0.53 & -0.38 & -0.18 & -0.33 & 0.35 & 0.25 & 0.27 & 0.12 \\
\hline Pigm & & & & & & & & $\cdots \cdots$ & -0.72 & 0.68 & 0.17 & 0.64 & -0.33 & -0.71 & -0.33 & -0.14 \\
\hline Depth & & & & & & & & & $\cdots$ & -0.91 & -0.51 & -0.58 & 0.41 & 0.17 & -0.18 & -0.18 \\
\hline Seston & & & & & & & & & & $\cdots$ & 0.74 & 0.66 & -0.48 & -0.08 & 0.24 & 0.17 \\
\hline Cond & & & & & & & & & & & $\cdots \cdots$ & 0.33 & -0.49 & 0.31 & 0.31 & 0.09 \\
\hline $\mathrm{NH}_{4}$ & & & & & & & & & & & & $\cdots$ & -0.41 & -0.24 & 0.17 & 0.07 \\
\hline $\mathrm{PO}_{4}$ & & & & & & & & & & & & & $\cdots$ & 0.05 & -0.14 & -0.02 \\
\hline Temp & & & & & & & & & & & & & & $\cdots \cdots$ & 0.59 & 0.44 \\
\hline Oxyg & & & & & & & & & & & & & & & $\cdots \cdots$ & 0.54 \\
\hline $\mathrm{pH}$ & & & & & & & & & & & & & & & & $\cdots$ \\
\hline
\end{tabular}


cell $^{-1}$, respectively, at 0.5 and $5 \mathrm{~m}$ depth. The highest values were observed during high water in August 1997. In 1998, minimum values of the index coincided with the dominance of Cylindrospermopsis raciborskii, but it is clear that this index is strongly influenced by the number of species accurring.

Table 3 lists the results of the Spearman correlations calculated between algal variables and abiotic parameters studied. Only the coefficients showing a significance level $<0.05$ are discussed. Significant relationships between Shannon index and algal groups were observed, with negative correlations for Cyanophyceae and Cylindrospermopsis raciborskii, and positive correlations for Chlorophyceae and Cryptophyceae. The indexes were negatively correlated with the chlorophyll level, suggesting that the algal diversity was higher when the trophic level (in terms of chlorophyll) was lower. Cyanophyceae and C. raciborskii biomasses evidenily showed the same correlations with abiotic variables. In particular, they were correlated negatively with the euphotic depth, and positively with chlorophyll level, suggesting that cyanobacterial development is responsible for the reduced euphotic zone by self shading. Among abiotic variables, a positive significant correlation was observed between $\mathrm{pH}$ values and dissolved oxygen concentrations, revealing a strong influence of the algal development during the survey.

\section{Bioassays for toxicity}

In April 1998, mouse death occurred within $5 \mathrm{~min}$ after injection when the dose administrated was $280 \mathrm{mg}$ dry weight $\mathrm{kg}^{-1}$ mouse live weight. For fish alevins, the lethal dose was $381 \mathrm{mg}$ dry weight $\mathrm{kg}^{-1}$ fish live weight in September 1998, with death occurring within 6 min after injection. In October 1998 the dose was lower (139 mg dry weight $\mathrm{kg}^{-1}$ fish live weight) for death occurring within $3 \mathrm{~min}$.

\section{DISCUSSION}

\section{Context of the study}

The catastrophic effects of the El Nino Southern Oscillation on the productivity of marine ecosystems in South America are well known (Cushing 1971), and these large and widespread changes affect planktonic communities at multiple trophic levels in various regions, e.g. picophytoplankton in the western tropical Pacific Ocean (Blanchot \& Rodier 1996). Since 1997, the impacts of the El Niño event have affected the climate in the Northeast of Brazil, especially the irregularities of the precipitation over the year. In our study, 2 recognizable steps can be identified: at the beginning in 1997, the water level was high with marked seasonal variations in abiotic parameters (conductivity, $\mathrm{pH}$, dissolved oxygen, chlorophyll); from March 1998, a new phase began with drought conditions and the gradual decrease in water level that coincided with the high development of one phytoplankton species inducing a bloom.

\section{Phytoplankton composition}

The composition of algal assemblage can be important for understanding the complexity of the processes in the system. According to Huszar et al. (1998), many of the trophic indexes developed for temperate regions (OECD 1982) could not be applied in tropical waters, and the phytoplankton assemblage appears more adequate for the resolution of trophic state in tropical regions. During the initial phase of the survey, Chlorophyceae and Bacillariophyceae were present until October 1997. According to Reynolds (1998), genera like Cyclotella are more frequently associated with moderately eutrophicated systems. Diversity ShannonWeaver index gave its highest values in the more disturbed periods, characterized by high precipitation and low chlorophyll concentrations. During the drought period, an evident trend of decrease in diversity is observed with an increase in Cylindrospermopsis raciborskii dominance. These low values might be attributed to the onset of nutrient depletion due to the dominance of the cyanobacterial competitor. The species C. raciborskii can proliferate until it represents close to $100 \%$ (with the precision error of algal counts) of the total algal composition over 9 mo (December 1997 to November 1998). For this species, this fact is more of an exception than a rule according to Padisák (1997). Very high biomass of C. raciborskii (70 $\mathrm{mg} \mathrm{l}^{-1}$ ) was noted close to the cyanobacterial peak (50 $\mathrm{mg} \mathrm{l}^{-1}$ ) reported in a hypereutrophic lake in Austria by Mayer et al. (1997). These high biomasses are generally considered as a characteristic of eutrophic environment. although Huszar et al. (1998) and Reynolds (1998) demonstrated that cyanobacteria can also represent an important part of phytoplankton in non-eutrophic tropical environments. According to the new classification established by Padisák \& Reynolds (1998), the dominance of $C$. raciborskii throughout the survey ( $2 \mathrm{yr}$ ) in poor light conditions and during the low water period allowed us to conclude that this cyanobacterial species can be defined as $S_{N}$ ( $S$ is an association in the phytosociological scheme of Reynolds 1996) species in terms of life strategies. One possible factor for the reapparition of Chlorophyceae and Bacillariophyceae after the bloom (October to December 1998) is the 
small ratio of the photic depth to the mixed depth due to the major decrease of the water level linked to the reservoir topography. In this context, thermic winds which characterize the region (no wind during the night) can induce sediment resuspension and liberate nutrients in the water column more easily as demonstrated in a shallow tropical lagoon (Arfi \& Bouvy 1995). Thus, C. raciborskii can lose their competitive advantage because nutrients become more available to all types of phytoplankton species that are more nutrient-dependent in the photic zone.

\section{Phytoplankton dynamics: influence of environmental conditions}

Many freshwater lakes and reservoirs with cyanobacteria dominance are mainly studied in the south part of Brazil characterized by high temperatures in summer (see de Souza et al. 1998). As in temperate regions (Couté et al. 1997. Wasmund 1997), these studies mention cyanobacterial blooms which generally occur for a short period (discrete daily dominance, months or season) when key factors are gathered to favor bloom development. The species Cylindrospermopsis raciborskii is cosmopolitan, which explains its invasion in tropical, subtropical and temperate regions (Padisák

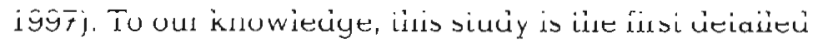
work on a toxic cyanobacterial bloom in a reservoir located in northeast Brazil, characterized by limnological and meteorological conditions far different to those observed in the reservoirs in the south of the country. Favorable temperature conditions occurred in Ingazeira reservoir during the survey, with values always higher than $24^{\circ} \mathrm{C}$ and no thermal stratification of the water column observed. Thus, temperature should not influence C. raciborskii development whereas this parameter plays a major role in other countries (e.g. Couté et al. 1997, Padisák 1998). In Ingazeira reservoir, conductivity values ranged between 611 and $1700 \mu \mathrm{S} \mathrm{cm}^{-1}$, and thus this species is able to tolerate large differences in ionic composition. C. raciborskii dominated over the entire survey while the $\mathrm{pH}$ values ranged between 8.1 and 9.4 during the bloom. This result corroborates the fact that the alkalinity system (carbon dioxide/pH) is an important determinant of algal community composition (Shapiro 1990, Caraco \& Miller 1998). Due to the lack of precipitation from August 1997 and the high evaporation rate in this region, the long retention time $\{2 y r$ in the reservoir studied favors eutrophic conditions and reduced light transparency and depth of photic zone. These poor light conditions in the water column are linked to the self shading of the cyanobacterial bloom, and represent for them ecologically favorable conditions. Our data about photon flux density at $0.50 \mathrm{~m}$ clearly showed that bloom of $\mathrm{C}$. raciborskii occurred during the lowest light intensities (<63 $\mu \mathrm{E} \mathrm{m}^{-2} \mathrm{~s}^{-1}$ between April and September 1998) and confirmed that photosynthesis of this species can be light-inhibited at relatively low $\left(<200 \mathrm{mE} \mathrm{m}^{-2} \mathrm{~s}^{-1}\right)$ light intensities (Padisák in press). As suggested by Paerl (1988) and Padisák (1997), the physical environment plays an important role for cyanobacteria growth, knowing that they strongly prefer the maintenance of environment stability.

The nutrient context also seems to play a positive role in the cyanobacterial bloom in Ingazeira reservoir. Cyanobacteria often develop rapidly at times when concentrations in the water are at their lowest levels. Présing et al. (1996) reported very low SRP concentrations $\left(<4 \mu \mathrm{g} \mathrm{l}^{-1}\right)$ during a bloom of Cylindrospermopsis raciborskii in Lake Balaton. This fact may not only be a cause but an effect of the rapid phosphate uptake by the phytoplankton, especially by cyanobacteria, storing phosphorus when it is available in high concentrations (Paerl 1988). In our study means of phosphate concentrations (SRP) were higher $\left(65\right.$ and $85 \mu \mathrm{g} \mathrm{l}^{-1}$ for the 2 levels studied) than the limiting level $\left(10 \mu \mathrm{g} \mathrm{l}^{-1}\right)$ stated by Steinberg \& Hartmann (1988). Indeed, these authors concluded that above this threshold, cyanobacterial development is regulated by physical factors such as water-column stability.

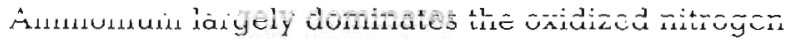
forms in Ingazeira reservoir and appears as the main source of dissolved nitrogen. Présing et al. (1996) demonstrated that during a bloom of Cylindrospermopsis raciborskii in Lake Balaton cyanobacteria take advantage of their ability to assimilate ammonium at low ambient concentrations. Padisák \& Istvánovics (1997) also reported similar negative correlations between ammonium concentrations and the biomass of heterocytic blue-green algae in the same lake. In our study ammonium concentrations were positively correlated with chlorophyll level, Cyanophyceae and $C$. raciborskii biomasses. These correlations can be explained indirectly by the high possible metabolic coupling existing between bacterioplankton and phytoplankton, as demonstrated by Bouvy et al. (1998c) in shallow tropical reservoirs in West Africa. In 1997 before the bloom, bacterial numbers in Ingazeira reservoir were significantly correlated with cyanobacterial density (Bouvy unpubl. data), suggesting a high degree of mineralization of dissolved organic matter by the bacterial communities with a supply of ammonium in the system. It is generally accepted that cyanobacteria dominate in conditions of reduced ratio of nitrogen:phosphorus and tend to form blooms when the ratio is below 29 (Smith 1983). Values close to 20 were observed by Mayer et al. (1997) and de Souza et al. (1998) in reservoirs with a possible dominance of 
cyanobacteria. In the Patos Lagoon estuary (Brazil), Microcystis blooms appear to be associated with a N/P ratio close to 13 (Yunes et al. 1996). In a hypereutrophic African lake, Zohary et al. (1996) reported a mean annual ratio below 3.5 during a Microcystis bloom, similar to that during the bloom in Ingazeira reservoir. Unfortunately, the N:P ratio was not available in 1997, but based on phosphate and ammonia concentrations, the ratio was low long before the bloom, suggesting that a low dissolved inorganic N:P ratio may be a prerequisite but not a cause for the cyanobacterial bloom. However, Reynolds (1998) argued that this resource-ratio theory is difficult to justify and cautioned the use of this parameter for predictions of algal dominance.

\section{Cylindrospermopsis raciborskii}

\section{Morphological characters}

Among the genus Cylindrospermopsis, the most widely distributed and well known is the pantropicaltype species C. raciborskii (Komárková 1998). Misinterpretation of the filaments without heterocytes and akinetes is easily possible, but not with C. Catemaco due to the small dimensions of their filaments (Komárková-Legnerová \& Tavera 1996). The other species C. philippinensis is more known but the position of akinetes is specific (Komárková-Legnerová \& Tavera 1996). During the survey, C. raciborskii filaments were coiled with a mean proportion of $97 \%$. However studies about blooms of $C$. raciborskii reported the presence of straight filaments (Rothhaupt 1991, Couté et al. 1997. Mayer et al. 1997, Thomas et al. 1998). Only 1 work (Fabbro \& Duivenvoorden 1996) revealed a bloom of predominantly coiled $C$. raciborskii, without reporting the percentage of coiled filaments. In a review about the genus Cylindrospermopsis, Komárková (1998) confirmed that C. raciborskii is a common species in freshwater plankton but in the form of straight trichomes. Recently, Saker et al. (1999) reported the presence of the 2 forms of $C$. raciborskii at Salomon Dam, Australia, and concluded that these 2 forms have clear and consistent morphological and physiological differences, although no genetic separation (from 16S rRNA gene nucleotide sequences) is observed between the 2 forms. These authors suggested that the dominance of the colled form in natural populations mainly occurred in destratified and unstable conditions. Our results from Ingazeira reservoir are contradictory, with a dominance of the coiled form in oxygen-stratified and stable conditions. In other hydrographic basins of Pernambuco state, we observed all the cases of Cylindrospermopsis forms, with the pres- ence of the 2 forms or only 1 dominant form (Bouvy unpubl. data). However, in agreement with Saker et al. (1999), the reason for the form change is not clear, but we think that the morphotype of C. raciborskii can change following the environmental conditions.

In our study, the coiled trichomes were composed of a variable number of cells with a length range of 42 to $194 \mu \mathrm{m}$ (mean: $97 \mu \mathrm{m}, \mathrm{n}=204$ ). Trichomes with terminal heterocytes were scarce with a mean proportion of $12 \%$, generally with the simultaneous development of 2 apical heterocytes (Bouvy unpubl. data). A similar proportion ( $8 \%$ ) was observed with the trichomes of Cylindrospermopsis raciborskii in the Paranoá reservoir (Branco \& Senna 1994). Thus in terms of physiology, this species is not stressed by atmospheric nitrogen fixation during the growth (and bloom) and directly uses the dissolved nitrogen forms. Knowing that ammonium is the preferred nitrogen form by $C$. raciborskii (Branco \& Senna 1994, Présing et al. 1996, Padisák 1997) and that inorganic nitrogen concentrations are relatively high in Ingazeira reservoir, the absence of heterocytes could be explained by the lack of trigger. Finally, a very small number of akinetes were found during the survey, suggesting that environmental conditions were not yet unfavorable for the growth of C. raciborskii.

It is interesting to speculate that one of the reasons for the scum formation of Cylindrospermopsis raciborskii in Ingazeira reservoir is the feature of the coiled form of trichomes. During the bloom, presence of scums was often detected early in the morning. In June 1998, chlorophyll concentrations showed the highest values (135 and $141 \mu \mathrm{g} \mathrm{l}^{-1}$, respectively, at 0.5 and $5 \mathrm{~m}$ ), and in the scum, concentrations increased $1600 \mu \mathrm{g} \mathrm{l}^{-1}$. However Padisák (1997) mentioned in a review that despite the good floating abilities of the C. raciborskii, reports for scum in the literature were absent, except for 1 report in a Kansas lake. According to Saker et al. (1999), the coiled form is characterized by its higher relative growth rates at lower light availability. In future, it would be interesting to investigate this hypothesis. Anyhow, in Ingazeira reservoir, all scum disappeared each day and returned the next day; this scum presence also seems strongly associated with meteorological variables (wind, precipitation, atmospheric pressure) as demonstrated by Soranno (1997).

\section{Toxicity}

The mouse bioassay has been the standard screening bioassay for toxins (Hughes et al. 1958), but due to our difficulties to obtain mice, we applied an alternative bioassay with fish which provided a measure of the total toxicity for routine toxin monitoring. These 
bioassays cannot explicitly identify the toxic agent, only a possible or likely mode of toxicity. Cyanobacteria were considered toxic if death occurred at doses below $1500 \mathrm{mg} \mathrm{kg} \mathrm{k}^{-1}$. All results reported in this study were below this dose, especially in October after the bloom of Cylindrospermopsis raciborskii. In mouse bioassays death by respiratory arrest occurs rapidly within 2 to $30 \mathrm{~min}$ with the neurotoxin presence in the cell extracts (see Chorus \& Bartram 1999). In the present case, death of mice always occurred within $10 \mathrm{~min}$ after injection and confirmed the presence of neutoxins in the cell extracts from Ingazeira samples during the C. raciborskii bloom (Molica et al. 1998). The chemical analysis of neurotoxins are being investigated by W. Carmichael's group (Wright State University, USA). Very few reports demonstrated that $C$. raciborskij is a producer of neurotoxin (Lagos et al. 1999). Previous works about Cylindrospermopsis only reported the presence of a cytotoxic alkaloid (called cylindrospermopsin; Ohtani et al. 1992).

\section{Zooplankton grazing}

It is well known that toxic cyanobacteria are harmful to feeding, growth and reproduction of many zooplankton species (Boon et al. 1994, Gilbert 1996).

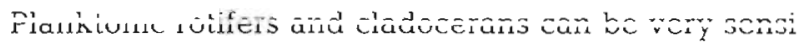
tive to toxic cyanobacteria (e.g. Smith \& Gilbert 1995). The structure of the zooplankton population found during the survey (Bouvy unpubl. data) consisted primarily of rotifers including 4 species of Brachionus and 2 species of Keratella, and secondarily of copepods with 1 calanoid and 1 cyclopoid. The peaks of rotifers and cyclopoids coincided with the Cylindrospermopsis bloom, suggesting that several species can benefit from feeding on cyanobacteria. However, preliminary experiments conducted in the laboratory, and based on grazing of Cylindrospermopis by different zooplankton groups (by size), revealed that all groups can cut filaments (before $48 \mathrm{~h}$ ) but only copepods can ingest the small lengths of coiled filaments of Cylindrospermopsis (Bouvy \& Molica 1999). Thus, despite the toxicity of Cylindrospermopsis, some species of zooplankton can utilize cyanobacteria for their growth. Further research will be based on 1 species of each zooplankton group. This result differs from Rothhaupt's (1991) conclusions which demonstrate that Brachionus may be negatively affected by the mechanical (rigid filaments) or biochemical (toxins) properties of $C$. raciborskii. Fabbro \& Duivenvoorden (1996) reported the absence of grazing for the dominant coiled forms during the bloom of C. raciborskii. The degree to which toxic cyanobacteria affect the zooplankton population may be greatly influenced by environmental factors.

\section{Causes of blooms}

Cyanobacterial blooms are often linked to external nutrient enrichment coinciding with a modification of temperature and light, but these conditions can be sometimes initiated by meteorological factors. Tóth \& Padisák (1986) explained the bloom of Cylindrospermopsis raciborskii in a temperate zone (Lake Balaton) by the high precipitation with the nutrient arrival. Fabbro \& Duivenvoorden (1996) suggested that several thunderstorms were responsible for the bloom of $C$. raciborskii in tropical Queensland with the downward thermocline movement probably inducing the akinete resuspension and the release of sediment-bound phosphorus. Harris \& Baxter (1996) concluded that the phytoplankton assemblages switched between cyanobacterial (C. raciborskil) and diatom blooms during the El Niño Southern Oscillation events in a subtropical reservoir. More recently, Padisák (1998) concluded that global changes drive modifications in the dynamics of phytoplankton with the example of a global warming affecting the frequency of the C. raciborskii blooms. Changes in climatological conditions linked to the 1997 El Niño phenomenon in northeast Brazil have modified the ecological conditions in many reservoirs. Droughts have induced a high water column stability (lack of turbulence), a long water retention time (lack of vator roncr.rall, a nutrient concentration in excellent conditions of temperature and irradiation. In 1995, the Ingazeira reservoir presented mesotrophic conditions (Bouvy et al. 1998a), but since 1997 to 1998, its trophic status has become hypertrophic with a bloom of 1 filamentous cyanobacteria. Thus, climate variability linked to the 1997 El Niño effects (and not directly external nutrient input) has been responsible for the seasonal and interannual changes on phytoplankton community in Ingazeira reservoir, as concluded by Harris \& Baxter (1996) and Padisák (1998) for other continental aquatic ecosystems.

\section{Conclusion and perspectives}

Global climate change can influence phytoplankton population dynamics in continental waters, as proven frequently in marine ecosystems. Physical and climatological factors are responsible for the ecological determinants of the cyanobacterial bloom in reservoirs located in the semi-arid region of Brazil. In 1998, cyanobacterial blooms of Cylindrospermopsis raciborskii were detected in many reservoirs of the same hydrographic basin, but also in other basins located in the semi-arid region of Pernambuco state (Pereira et al. 1999). Blooms have induced numerous effects on environmental conditions such as water column deoxy- 
genation, presence of toxins, nutrient concentrations, chemistry and biological changes. Considering the regional and economical context and the present climatic conditions, toxic cyanobacterial blooms have dramatic consequences for the populations of northeast Brazil. Furthermore, the population of Pernambuco state living near reservoirs remembers the Caruaru tragedy which occurred in 1996 (Azevedo 1996, Carmichael 1996, Jochimsen et al. 1998). A monitoring program has been established for a limnological survey of main drinking water reservoirs. In future research, our goal is to elucidate the taxonomic significance of numerous morphotypes of Cylindrospermopsis by a genetical approach in order to discover the influence of environmental conditions in relation to genetic causes.

Acknowledgements. The authors are indebted to Dr J. Padisák for constructive comments and helpful discussions. We are grateful to the 3 other reviewers for their criticisms. We would like to thank Dr Jaroslava Komárková (Academy of Sciences of the Czech Republic) for her help in the determination of the coiled form of Cylindrospermopsis raciborskii, and information regarding this genus. Sincere thanks to Dr W. Carmichael and his group (Wright State University, USA) for toxin analysis and identification. We also thank R. Arfi and J. $P$. Torreton for correcting the English and for their comments on an earlier draft of the manuscript. This work is part of the IRD/UFRPE 'Açudes' Project.

\section{LITERATURE CITED}

Arfi R, Bouvy M (1995). Size composition and distribution of particles related to wind induced resuspension in a shallow tropical lagoon. J Plankton Res 17:557-574

Azevedo SMFO (1996) Toxic cyanobacteria and the Caruaru tragedy. Proc IV Symp Brazilian Soc Toxicol 83

Barber RT, Sanderson MP, Lindley ST, Chal F, Newton J, Trees CC. Foley DG, Chavez FP (1996) Primary productivity and its regulation in the equatorial Pacific during and following the 1991-1992 El Niño. Deep-Sea Res 43: 933-969

Blanchot J, Rodier M (1996) Picophytoplankton abundance and biomass in the western tropical Pacific Ocean during the 1992 El Niño year: results from cytometry. Deep-Sea Res 43:877-895

Boon PI, Bunn SE, Green JD, Shiel RJ (1994) Consumption of cyanobacteria by freshwater zooplankton; implications for the success of 'top down' control of cyanobacterial blooms in Australia. Aust $\mathrm{J}$ Mar Freshw Res 45:875-887

Bouvy M, Molica RJR (1999) Avaliação da ingestāo de Cylindrospermopsis pelo zooplancton: testes em laboratório. Anais do VII Congresso Brasileiro Ficologia, 22-26 September 1999, Porto de Galinhas, Brazil, p 161

Bouvy M, Barros Franca L, Carmouze JP (1998a) Compartimento microbiano no meio pelágico de sete açudes do estado de Pernambuco (Brasil). Acta Limnol Brasil 10: 93-101

Bouvy M, Beker B. Molica RJR, Nascimento S (1998b) Bloom of a toxic cyanobacteria Cylindrospermopsis raciborskii in an eutrophic reservoir of the Brazilian Northeast semi-arid region: ecological and human consequences. Congress of
Potentially Toxic Freshwater Cyanobacteria, Paris, 24-27 May 1998

Bouvy $M$, Arfi $R$, Cecchi P, Corbin D, Pagano M, Saint-Jean L, Thomas S (1998C) Trophic coupling between bacterial and phytoplanktonic compartments in shallow tropical reservoirs (Côte d'Ivoire, West Africa). Aquat Microb Ecol 15: $25-37$

Branco CWC, Senna PAC (1994) Factors influencing the development of Cylindrospermopsis raciborskii and Microcystis aeruginosa in Paranoá reservoir, Brasília, Brazil. Algol Stud 75:85-96

Cadier E (1993) Hydrologie des petits bassins du Nordeste brésilien semi-aride-transposition à des bassins non étudiés. Thesis, ORSTOM, Paris

Caraco NF, Miller $\mathrm{R}$ (1998) Effects of $\mathrm{CO}_{2}$ on competition between a cyanobacterium and eucaryotic phytoplankton. Can J Aquat Sci 55:54-62

Carmichael WW (1994) The toxins of cyanobacteria. Sci Am 270:78-86

Carmichael WW (1996) Liver failure and human deaths at a haemodialysis centre in Brazil: microcystins as a major contributing factor. In: Harmful algal news, Vol 15. IOC UNESCO, Paris, p 11

Chorus I, Bartram J (1999) Toxic cyanobacteria in water. A guide to their public health consequences, monitoring and management. E \& FN Spon, London.

Couté A, Leitao M, Martin C (1997) Première observation du genre Cylindrospermopsis (Cyanophyceae, Nostocales) en France. Cryptogam Algol 18:57-70

Cushing DH (1971) Upwelling and the production of fish. Adv Mar Biol 9:255-334

de Souza RCR, Carvalho MC, Truzzi AC (1998) Cylindrospermopsis raciborskii (Wolsz.) Seenayya et Subba Raju (Cyanophyceae) dominance and a contribution to the knowledge of Rio Pequeno Arm, Billings reservoir, Brazil. Environ Toxicol Water Qual 13:73-81

Fabbro LD, Duivenvoorden LJ (1996) Profile of a bloom of the cyanobacterium Cylindrospermopsis raciborskii (Woloszynskal Seenaya and Subba Raju in the Fitzroy River in tropical central Queensland. Mar Freshw Res 47:685-694

Gilbert JJ (1996) Effect of food availability on the response of planktonic rotifers to a toxic strain of the cyanobacterium Anabaena fos-aquae. Limnol Oceanogr 42:1565-1572

Harris GP, Baxter G (1996) Interannual variability in phytoplankton biomass and species composition in a subtropical reservoir. Freshw Biol 35:545-560

Hughes EO, Gorham PR, Zehnder (1958) Toxicity of a unialgal culture of Microcystis aeruginosa. Can J Microbiol 4: $225-236$

Humpage AR, Rositano J, Baker PD, Nicolson BC, Steffesen DA, Bretag AH, Brown RK (1993) Paralytic shellfish poisons from freshwater blue-green algae. Med J Aust 159:423

Huszar VLM, Silva LHS, Domingos P, Marinho M, Melo S (1998) Phytoplankton species composition is more sensitive than OECD criteria to the trophic status of three Brazilian tropical lakes. Hydrobiologia 369/370:59-71

James RT, Havens KE (1996) Algal bloom probability in a large subtropical. lake. Water Res Bull 32:995-1006

Jochimsen EM, Carmichael WW, An J, Cardo DM, Cookson ST, Holmes CEM, Antunes BC, Melo Filho DA, Lyra TM, Barreto VST, Azevedo SMFO, Jarvis WR (1998) Liver failure and death after exposure to microcystins at a hemodialysis center in Brazil. New Engl J Med 338: $873-878$

Jones GJ, Poplawski W (1998) Understanding and management of cyanobacterial blooms in sub-tropical reservoirs of Queensland, AustraLia. Water Sci Technol 37:161-168 
Komárková J (1998) The tropical planktonic genus Cylindros permopsis (Cyanophytes, cyanobacteria). In: Azevedo $T$, de Paiva T (eds) Anais do IV Congresso Latino Americana de Ficologia, Brazil, Secretaria do Meio Ambiente do Estado de Sào Paulo, Vol I, p 327-340

Komárková-Legnerová J, Tavera R (1996) Cyanoprokaryota (Cyanobacteria) in the phytoplankton of Lake Catemaco (Veracruz, Mexico). Algol Stud 83:403-422

Lagos $N$, Onodera $H$, Zagatto PA, Andrinolo D, Azevedo SMFQ, Oshima $Y$ (1999) The first evidence of paralytic shellfish toxins in the freshwater cyanobacterium Cylindrospermopsis raciborskii, isolated from Brazil. Toxicon 37:1359-1373

Liu WT, Tang W, Hu H (1998) Spaceborne sensors observe El Nino's effects on ocean and atmosphere in north Pacific. EOS 79:249-252

Mayer J, Dokulil MT, Salbrechter M, Berger M, Posch T, Pfister G, Kirschner AKT, Velimirov B, Steitz A, Ulbricht T (1997) Seasonal successions and trophic relations between phytoplankton, zooplankton, ciliate and bacteria in a hypereutrophic shallow lake in Vienna, Austria. Hydrobiologia 342/343:165-174

Molica R, Nascimento S, Bouvy M, Silva N (1998) Neurotoxic Cylindrospermopsis sp. blooms in Brazilian waterbodies. 4th Int Conf Toxic Cyanobacteria, North Carolina, USA. 27 Sept-1 Oct 1998

Molle F (1991) Caractéristiques et potentialités des 'Açudes' du nordeste brésilien. Thesis, USTL, Montpellier

OECD (1982) Eutrophication of waters. Monitoring, assessment and control. OECD, Paris

Ohtani I, Moore R, Runnegar MTC (1992) Cylindrospermopsin: a potent hepatotoxin from the blue green-alga Cylindrospermopsis raciborskii. J Am Chem Soc 114: 7941-7942

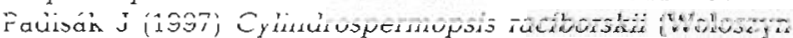
ska) Seenayya et Subba Raju, an expanding, highly adaptive cyanobacterium: worldwide distribution and review of its ecology. Arch Hydrobiol Suppl 4:563-593

Padisák J (1998) Sudden and gradual responses of phytoplankton to global climate change: case studies from two large, shallow lakes (Balaton, Hungary; Neusiedlersee, Austria/Hungary). In: George DG, Jones JG, Puncochar P, Reynolds CS, Sutcliffe DW (eds) Management of lakes and reservoirs during global change. Kluwer Acad Publ, Dordrecht, p 111-125

Padisák J (1997) The phytoplankton. In: O'Sullivan P, Reynolds CS (eds) The lakes handbook. Blackwell Science Ltd, Oxford, Chapter 3

Padisák J, Istvânovics V (1997) Differential response of bluegreen algal groups to phosphorus load reduction in a large shallow Lake Balaton, Hungary. Verh Int Ver Limnol $26: 574-580$

Padisák J, Reynolds CS (1998) Selection of phytoplankton associations in Lake Balaton, Hungary, in response to eutrophication and restoration measures, with special reference to the cyanoprokaryotes. Hydrobiologia 384: $41-53$

Paerl HW (1988) Nuisance phytoplanktonic blooms in coastal, estuarine and inland waters. Limnol Oceanogr 33:823-847

Pereira DF, Bouvy M, Marinho M, Moura A do N (1999) Microfitoplâncton e condições limnológicas em reservatórios de cinco bacias hidrográficas do Estado de Pernambuco: ênfase ao gênero Cylindrospermopsis. Anais do VII Congresso Brasiliero Ficologia, 22-26 September 1999, Porto de Galinhas, Brazil, p 120

Présing M, Herodek S, Vörös L, Kóbor I (1996) Nitrogen fixation, ammonium and nitrate uptake during a bloom of

Editorial responsibility: William Li

Dartmouth, Nova Scotia, Canada
Cylindrospermopsis raciborskii in Lake Balaton. Arch Hydrobiol 136:553-562

Reynolds CS (1988) Functional morphology and the adaptive strategies of freshwater phytoplankton. In: Sandgren CD (ed) Growth and reproductive strategies of freshwater phytoplankton. Cambridge University Press, New York, p $388-433$

Reynolds CS (1996) The plant life of the pelagic. Verh Int Ver Theor Angew Limnol 26:97-113

Reynolds CS (1998) What factors influence the species composition of phytoplankton in lakes of different trophic status? Hydrobiologia 369/370:11-26

Rothhaupt KO (1991) The influence of toxic and filamentous blue-green algae on feeding and population growth of the rotifer Brachionus rubens. Int Rev Ges Hydrobiol 76:67-72

Rott HE (1981) Some results from phytoplankton counting intercalibrations. Schweiz Z Hydrol 43:34-62.

Saker ML, Neilan BA, Griffiths DJ (1999) Two morphological forms of Cylindrospermopsis raciborskii (Cyanobacteria) isolated from Solomon Dam, Palm Island, Queensland. J Phycol 35:599-606

Shannon CE, Weaver W (1963) The mathematical theory of communication. Illinios University Press, Urbana

Shapiro J (1990) Current beliefs regarding dominance by blue green-algae: the case for the importance of $\mathrm{CO}_{2}$ and pH. Verh Int Verein Theor Angew Limnol 24:38-54

Smith AD, Gilbert JJ (1995) Relative susceptibilities of rotifers and cladocerans to Microcystis aeruginosa. Arch Hydrobiol 132:309-336

Smith VH (1983) Low nitrogen to phosphorus ratios favor dominance by blue-green algae in lake phytoplankton. Science 221:669-670

Soranno PA (1997) Factors affecting the timing of surface scums and cpilimnotic blooms of blue-groen algae in a eutrophic lake. Can J Fish Aquat Sci 54:1965-1975

Steinberg EW, Hartmann HM (1988) Plankton bloom-forming cyanobacteria and the eutrophication of lakes. Freshw Biol 20:279-287

Strickland JDH, Parsons TR (1972) A practical handbook of seawater analysis. Bull Fish Res Bd Can 167

Thomas AD, Saker ML, Norton JH, Olsen RD (1998) Cyanobacterium Cylindrospermopsis raciborskii as a probable cause of death in cattle in northern Queensland. Aust Vet J 76:592-594

Toth GL, Padisák J (1986) Meteorological factors affecting the bloom of Anabaenopsis raciborskii Wolosz. (Cyanophyta: Hormogonales) in the shallow lake Balaton, Hungary. J Plankton Res 8:353-363

Townsend SA, Luong-Van JT, Boland KT (1996) Retention time as a primary determinant of colour and light attenuation in two tropical Australian reservoirs. Freshw Biol 36 $57-69$

Uhelinger V (1964) Étude statistique des méthodes de dénombrement planctonique. Arch Sci 17:121-123

Wasmund N (1997) Occurrence of cyanobacterial blooms in the Baltic Sea in relation to environmental conditions. Int Rev Ges Hydrobiol 82:169-184

Yentsch CS, Menzel DW (1963) A method for the determination of phytoplankton chlorophyll and pheophytin by fluorescence. Deep-Sea Res 10:221-231

Yunes JS, Salomon PS, Matthiensen A, Beattie KA, Raggett SL, Codd GA (1996) Toxic blooms of cyanobacteria in the Patos Lagoon Estuary. J Aquat Ecosyst Health 5:223-229

Zohary T, Pais-Madeira AM, Robarts R, Hambright KD (1996) Interannual phytoplankton dynamics of a hypereutrophic African lake. Arch Hydrobiol 136:105-126

Submitted: July 15, 1999; Accepted: October 14, 1999

Proofs received from author(s): December 9, 1999 